\title{
Explorative Study of Online Learning on Salesmanship Course in Covid-19 Pandemic
}

\author{
Harti $^{1,{ }^{*}}$ Raya Sulistyowati ${ }^{1}$ Tri Sudarwanto ${ }^{1}$ Septyan Budi Cahya ${ }^{1}$ Veni Rafida ${ }^{1}$ \\ ${ }^{1}$ Business Education, Surabaya State University Surabaya, Indonesia \\ *corresponding author.Email: harti@unesa.ac.id
}

\begin{abstract}
This study aims to explore the application of learning salesmanship courses during the COVID-19 pandemic, where there are social policies and physical distance conducted by online lectures, while salesmanship courses will be effective if done with many direct practices. Approved implementation of planning, implementation, and evaluation of the implementation of online learning with the support of learning applications such as learning modules and videos. This research was conducted using descriptive qualitative, discussion, and collect data about responses and submissions of learning applications consisting of modules and video sales used during the online learning process. The technique of collecting data is done by collecting, observing, and questioning. Data were analyzed qualitatively using NVIVO software. The results showed that learning tools in the form of salesmanship modules and videos received very high responses, and were effective in fostering student interest in learning, the results of data analysis showed that with modules and videos made learning salesmanship easier, especially on the topic of effective selling techniques online at a pandemic period, very relevant to current needs.
\end{abstract}

Keywords: online learning, salesmanship, modules, learning videos

\section{INTRODUCTION}

The spread of Coronavirus Disease (COVID-19) is increasingly getting worse in Indonesia. Of course, we all hope that this outbreak will end soon because this problem does not only affect the health sector but also affects other fields such as the economy, tourism, and others. This outbreak also greatly impacted our education, where the Central and Regional Governments were forced to issue policies to close the process of learning activities. The central government through the Ministry of Education and Culture issued a policy by issuing Circular Letter No. 4 of 2020 concerning the Implementation of Education in the Coronavirus Disease Emergency Period (COVID-19). Two important policies from the circular letter are schools conduct Distance Learning Process (PJJ) to students, and cancel the implementation of the National Examination.

The corona virus pandemic or COVID-19 in Indonesia caused many universities and schools to stop the process of face-to-face learning. Instead, learning is done remotely. Minister of Education and Culture (Mendikbud) Nadiem Makarim also seeks to build cooperation with various parties that focus on developing online education systems. The application of online learning requires the readiness of various parties, both from education service providers or from students themselves. This condition forces us to see the reality that the world is changing. We can see how the changes in the fields of technology, economics, politics to education amid the crisis due to Covid-19. These changes require us to prepare ourselves, respond with attitudes and actions while always learning new things.

Online learning is indeed not a new thing for universities, because many universities have innovated and developed online learning to improve their quality. However, the implementation of the physical distancing policy which later became the basis for implementing learning from home with the use of information technology that applies suddenly, certainly shocked all elements in the learning activities process. Starting from educational institutions, lecturers and students need preparation and re-planning in carrying out the process of learning activities to run well.

Salesmanship is a course in the Business Administration Education program that discusses knowledge about products and marketing strategies, recognizes and deals well with customers, and can form networks with the business world, as well as excellent and after-sales services. In the lecture implementation plan, previously it was carried out by 
lecturing, discussion, observation, case studies, presentations, and reflections conducted by the faceto-face learning process. This subject is one of the subjects taught during the COVID-19 pandemic so that in the learning process, the distance learning systems use online classes. This will certainly change the plan and implementation that has been made previously. Something that becomes a challenge for lecturers and students in these changes, especially in this subject not only requires deepening of theoretical material but also in practice.

Seeing the implementation of the system that is run due to reasons that were not previously thought, it needs to be investigated how the application of online learning relates to planning, implementation, evaluation, and follow-up of learning which has been conducted, as well as the impacts and constraints in the learning process.

Based on this background, the formulation of the problem in this study are (1) How is online learning planning in the salesmanship course in the middle of the COVID-19 pandemic?; (2) How is the implementation of online learning in salesmanship courses in the middle of the COVID-19 pandemic; (3) What are the results and follow up for online learning in the salesmanship course amid the COVID-19 pandemic; (4) What obstacles are faced and how to overcome the obstacles that exist in the application of online learning in salesmanship courses amid the COVID-19 pandemic?

The learning activity cannot be separated from teaching and learning. It is because in a learning activity there are learning and teaching activities that are running. In particular, teaching and learning processes will occur interactions between students and educators. Students or learners are one of the human components that occupy a central position in the teaching-learning process. In his book, [1] state that learning the translation of the word "instruction" which means self-instruction (from internal) and external instructions (from external). Furthermore, the external instruction in learning comes from the teacher called teaching. In external learning, the principles of learning will automatically become learning principles. Learning is conducted to help students gain a variety of experiences of knowledge, skills, and values or norms that function as controllers of students' attitudes and behavior. Learning objectives describe the ability or level of mastery that is expected to be achieved by students after they have followed a learning process.

It is said that many experts argue about the purpose of learning. The definition of learning from various viewpoints of experts have in common between one another. earning objectives as behaviors that want to be achieved or that can be done by students at certain conditions and levels of competence. The definition of learning was also expressed by [2] who considered that the learning objective was a specific statement expressed in behavior or appearance that was manifested in written form to describe the expected learning outcomes. This behavior can be in the form of concrete facts and can be seen and vague facts.

From the various definitions of experts, it can be concluded that the learning objectives provide understanding to students and the aimed understanding can be in the form of knowledge, experience, and application of existing values and norms so that changes in attitudes and behavior as well as increased knowledge in students.

In a distance learning course, we need a media that can distribute knowledge and become a tool for teaching and learning activities. Meanwhile, the media tools used in distance learning nowadays is the internet and a website which become a container in the form of online learning. Online learning can be interpreted as a computer network that is interconnected with other computer networks throughout the world. Distance learning has supported people who have difficulty attending classes by giving them opportunities to learn. Students who learn from distant locations are given instructions, assignments, and feedback through the method of correspondence, usually by letter [3].

Online distance learning implements a web-based online learning system. The online distance learning model begins with good planning, then the way the learning material is delivered (delivery content) to the learners who refer to the design. The online learning system is also different from the conventional teaching system. Online-based learning requires adequate infrastructure and supporting technologies such as computers, satellites, televisions and internet networks. There are 3 functions or potentials of online learning that can be utilized in everyday life, namely as a communication tool, a means of accessing information, and an educational or learning tool. In implementing online learning, E-learning has been introduced as a tool in the learning process at most universities. The term "elearning" is defined by [4] as "any learning that involves the use of the internet or intranet." [5] makes the definition more generalized by showing that it is "whatever is conveyed, activated, or mediated by electronic technology for the purpose of explicit learning".

Planning can be defined as a process of developing an anticipatory step to minimize the risk of failure so that the activity can run well and achieve goals in an effective and efficient manner. Learning has the nature of planning or design as an effort to make the students learn. As a result, in learning, students not only interact with the teacher as a source of learning, but also may interact with the whole learning resources used to achieve the desired learning goals. The efforts to improve the learning process are carried out with assumptions, to improve the quality of learning begins with learning planning that is realized with the learning design. 1) Identifying general learning objectives, 2) conducting teaching analysis , 3) identifying student input behavior and characteristics, 4) formulating learning objectives,

5) developing benchmark reference test items, 6) elaborating teaching strategies , 7) enlarging and select teaching material , 8) designing and carrying out normative 
evaluation, 9) revising learning materials and, 10) designing and carry out summative evaluation .

The implementation of learning is the process of realization of the planning (design) of learning. [6] the implementation of learning is the result of integration from several components that have their own functions with the aim that the achievement of learning objectives can be influenced. The linkages between the implementation of learning and distance learning have differences considering the learning process in distant learning in particular does not involve face to face directly in its implementation. As stated by [7] distance learning is the learning that emphasizes how to study independently (selfstudy). Independent learning is systematically organized in presenting learning materials, providing guidance to learners, and supervising the learners' success. The principles of implementing distance learning that must be met in its application are as follows: 1) clear objectives, 2) relevant to needs, 3) quality of education, 4) efficient and effective programs, 5) equity and expansion of learning opportunities, 6) independence, 7) cohesiveness, and 8) continuity. In a distance learning implementation, the role of the media as a means of delivering teaching materials to students greatly influences the level of success in teaching and learning activities. Selection of the right media can help students' understanding in processing learning material (teaching material).

The process of implementing online learning also requires lecturer activities to stimulate students to increase participation. To stimulate students, teachers must pay attention to: 1 . Keep in mind that motivation must be created naturally by students. 2 . Explain to their students how the online environment can be used. 3. Encourage interaction and collaboration among their students. 4. Build study groups thus students will be no longer study separately. 5. Help students to make friends by meeting fellow students in an online environment. 6. Interact with their students by monitoring their online presence and providing them with continuous feedback. 7. Build materials and their learning environment to target their students. 8. Facilitate student interaction with online material by explaining the purpose behind the designated assignment. 9. Become aware of students' fears, worries, and anxieties because such anxieties can negatively affect their accessibility and motivation.

It also needs anticipation that might occur in the implementation of online learning. As [8] explained, online learning has no direct contact with lecturers, which can make students feel that they are "teaching themselves". So there is a need for assistance and guidance in learning. Time zone differences [9] and conflicting schedules can prevent students from attending synchronous sessions [10] In addition, technical difficulties have been reported in several studies as a disadvantage to video conferencing. For example, audio problems often cause students to switch to the chat function rather than using a microphone [11]. Poor audio and video quality can cause delays and disrupt communication [12] and delivery of the learning content [10]. Having a weak internet connection is a further obstacle to a successful online experience [13] Furthermore, [14] argues that online learning is more than content delivery but more as a tool of learning that involves tutor's support and peer interaction. The issues needs to be considered therefore the implementation of online learning can be done in accordance with the expectations of the teacher and the students.

In the learning evaluation stage, the process of determining the value of learning implementation takes place through assessment activities. Devies in [15] defines evaluation as a simple process of assigning values to a number of goals, activities, decisions, performance, processes, people, objects, and many others. While Warn and Born argue that evaluation is a process of giving or determining value. Self-evaluation according to [16] is an ongoing process of gathering and interpreting information to assess the decisions made in designing a teaching system.

mentions the function and purpose of learning evaluation with more complexity which refers to the function of the evaluation itself as a curriculum system, among others: 1) determining the number of progress or student learning outcomes, 2) placing students into learning situations teaching is appropriate and compatible with the level of ability, interest, and various characteristics possessed by each student, 3) recognizing the background of students (psychological, physical, and environmental), 4) as feedback for teachers who in turn can be used to improve the process teaching and learning and remedial programs for students.

The types of evaluation of learning according to [16] there are 4, among others: 1) Summative evaluation, determining the rate of progress of student learning outcomes. 2) Evaluation of placement, to place students in matching learning and teaching situations. 3) Diagnostic evaluation, to help students overcome the learning difficulties they face. 4) Formative assessment that serves to improve the teaching and learning process. In evaluating learning outcomes, it is demanded to thoroughly evaluate students, both in terms of their understanding of the material that has been given (cognitive aspects), and in terms of appreciation (affective aspects) and their experiences (psychomotor aspects)

\section{RESEARCH METHODOLOGY}

This research is an exploratory case study to obtain information about the implementation of online learning in the salesmanship course during the Covid 19 pandemic using a descriptive qualitative approach. Qualitative research is an in-depth, case-oriented study from a small number of cases, including one case study. [17] Descriptive qualitative research contributes a lot to science through providing current state information, and can help in identifying factors that are useful for conducting experiments.

Sources of data in this research is primary and secondary data where primary data in this study were obtained through observation and interviews with students and lecturers from Business Administration 
Education program in State University of Surabaya, relating to the implementation of online learning accomplishments in distance education. While secondary data in this study were obtained from books, encyclopedias, articles, journals, or other writings related to the research.

In addition to online teaching and learning activities, the learning modules and videos are used as learning media. Clearly, the module contains complete learning material and the video as media used to help students know more, understand until they have a real picture of salesmanship activities, both of which will become objects research whether the learning modules and videos effectively replace practices that should be learning activities or not. In general, this study covers all aspects of the learning process, ranging from learning planning activities, implementation of learning to the evaluation process.

The sample size is determined based on the need to achieve depth and richness of description. According to [18] sample size is not a matter of representative opinion and views, but rather a matter of information wealth. The populations and samples in the study were the lecturers who taught the salesmanship course and the students who attended the salesmanship course at the Business Administration Education program at the Faculty of Economics, State University of Surabaya. To be more specific, the respondents were the students from class 2018 and class 2017 both from class A and class B.

To conduct case study research, [19] provides several recommendations for observations and sample sizes, ranging from no more than four to five. In the case study, respondents were interviewed until data saturation was reached, and no new information was obtained. The research instrument was using interview guide in which the structured interview had been done to the two lecturers courses and students from Business Administration Education class 2017 and 2018 where in each class is represented by one student.

The lecturer interview guidelines are as follows.

\section{1) Planning}

a) What is planned in implementing online learning in salesmanship courses in the midst of the covid-19 pandemic?

b) How is the preparation of the material to be delivered in online learning?

c) How do you plan to use media in online learning?

d) How is planning assessment in online learning? e) What obstacles are faced and how to overcome the obstacles that exist in planning online learning?

2) Implementation

a) How is the implementation of online learning in the distance education system conducted in the Salesmanship course?

b) What application is used in the online learning process?

c) What forms of supervision in online learning?

d) What is the response of students in participating in online learning?

e) What obstacles are faced and how to overcome the obstacles that exist in the implementation of online learning?

\section{3) Evaluation and Follow Up}

a) How do you evaluate the results of online learning in the distance education system conducted in the Salesmanship course?

b) What formative and summative evaluations are used in assessing online learning outcomes?

c) What is the percentage of assessment of learning outcomes ranging from formative, summative, and active students in online learning?

d) If the student learning outcomes are less than the standard value, how is the follow up?

e) What obstacles are faced and how to overcome the obstacles that exist in the evaluation and follow up on learning outcomes online learning?

The Student interview guidelines are as follows.

1) Planning

a) Is the lecturer very clear in providing online lecture planning?

b) Do students know the RPS used in online lectures?

c) Does the RPS used is easier for students to attend online lectures?

d) Does the lecturer explain the plan of activities in online lectures?

e) Are Modules and Video compliant with RPS?

f) What obstacles are faced and how to overcome the existing obstacles before attending online lectures?

\section{2) Implementation}

a) How do the online lectures in the distance education system take place in the Salesmanship course?

b) Are online lectures easy to access? 
c) In your opinion, how does the online lecture look like?

d) Are the Lecturers good enough in presenting material and guiding online lectures?

e) What media are used by lecturers in online lectures?

f) Is the media used easy to access and understand?

g) Is the media used interesting and innovative?

h) Are there specific guidelines in the online lecture process?

i) Is there a perceived difference between online lectures and face-to-face lectures?

j) Does the lecturer continue to guide in online lectures?

After getting the interview data the next step is to read the data and then present it into the research results. In this study the process of coding or reading the results of interviews that were presented to the conclusion of the study was carried out if the researcher had gotten the results of respondents saturated answers to then be processed using the NVIVO application. The result of this saturated answer is the same respondent's answer even though the questions have been repeatedly given. This is to avoid the statement of bias from respondents.

\section{RESULTS AND DISCUSSION}

Result of Lecturer Interview Data show the lecturer planned in implementing online learning in salesmanship courses in the middle of the covid-19 pandemic is started from the RPS, material, the media which is used are the assessment method, assignments and final exam. The second lecturer said that Modules, media, RPS, assessment, Tasks, Final Exam is the attribute.

Result of what kind of material that delivered by lecturer in online learning is arranged the same as the RPS, only different media, in general, almost the same, but it must be rethought about how the practice should be controlled.

The chosen online learning media must be easily accessible to students with minimal quota and guaranteed continuity. Because it is undeniable that some students have problems in terms of smooth access. Then for learning media there are modules and videos, this is adjusted to the learning objectives in the RPS.

For media in terms of online learning intermediaries I prefer the WhatsApp application and also Google classroom, because their features are simpler and easier to understand and also easily accessed. For learning media, I used modules and videos, sometimes with voice notes when there is discussion in the Whatsapp group.
From the answer of first lecturer, assessment will be adjusted to the activeness and process when conducting discussions, assignments and final exam score, in general the assessment process is not much different from face-to-face learning. Second lecturer said that assessment used is the same as the face-toface evaluation process, including the assessment of participation, assignment assessment, final exam, and mid-semester exam.

About obstacles are faced and how to overcome the obstacles that exist in planning online learning both says that there are a number of students who find it difficult to attend lectures due to bad signals and also the difficulty of monitoring anyone who is active in online learning due to media limitations. How to overcome attendance at the end of the session and also the learning process is done with an easily accessible media such as Whatsapp where all students have an account and the application.

About the implementation, they say is perfunctory, because this online learning position is impromptu, they tried optimally prepare all the media up to the teaching material, it still needs a lot to learn about distance education systems like this. The other lecturer say that implementation is made simple but according to the portion where indeed in distance learning or online learning it still needs a lot of things that need to be fixed and when learning takes place on the official website of Vlearn Unesa, it is difficult to access.

The applications thay they used in the online learning process are ZOOM, Google Meet, Whatsapp, Google Classroom. And about forms of supervision in online learning, they usually done with attendance check at the end because if the absence is done at the beginning, many students will just attend for a while then when learning takes place they will leave.

The response of students in participating in online learning is quite good but they complain with the large number of tasks given with a short grace period. Moreover supervision in the learning process is rather loose so it is prone to skipping, the learning process is sometimes interrupted by the network, obstacles in assigning tasks to replace field practice.

About the evaluation in formative forms is assignments and they were directly collected that day. We can also give them task to summarize or even give quizzes or project. As for the summative evaluation are mid-semester exam and final exam.

The percentage of assessment of learning outcomes ranging from formative, summative, and active students in online learning is accordance with UNESA policy and there are additional tasks or remedies if the student learning outcomes are less 
than the standard value. The biggest challenge comes especially in the salesmanship course in which is in this course should produce a skill which is assessed directly but it became difficult when a pandemic happened.

From Student Interview data they say that all lecturers very clear in providing online lecture planning, especially at the beginning of the meeting the lecturers always explain about the learning process that will be carried out as the final goal. All students know the RPS to it because they can download at their siakadu (academic system of UNESA). All student said that the lecturers explain the plan of activities in online lectures, and make they easy to understanding the course. About Modules and Video all compliant with RPS.

The constraints on network problems sometimes makes the class is longer than usual because the process is sometimes we cannot do the interface, other student say that network constraints, sometimes the media is too heavy and large, especially video, there are quite a lot of quota used.

About the implementation of online lectures in the distance education system conducted in the Salesmanship course, majority of the student said that it was quite fun in the beginning but on certain materials which should have been done direct practice was less than optimal, the other said that is quite fun to share videos that are also interesting but the tasks are piling up, they also argue that online lectures easy to access although sometimes the network couldn't unpredictable. They agree that online lecture are simple, easy to understand and use but not communicative. This is the same as [20] The challenges associated with students in online learning are limited communication and socialization.

The media are used by lecturers in online lectures are videos, modules, PPT, and they agree that the media is easy to access and easy to understand, but they feel if the media isn't interesting and innovative. [21] reveals several factors that can create attractive learning experiences for online learners are creating and maintaining a positive learning environment, building learning communities, providing consistent feedback on time, and using the right technology to deliver the right content. This was understood by the lecturers, but due to the sudden implementation of online learning due to a pandemic, media preparation for the implementation of online learning was not optimal.

About what is the difference felt between online lectures and face-to-face lectures their answer are Online lectures accumulate assignments, but they can be done anytime and anywhere and online lectures more simpler. Here are the results of the questionnaire response in the study.
Table 1. Questionnaire Result

\begin{tabular}{|c|c|c|c|c|c|c|}
\hline \multirow{2}{*}{ No } & \multicolumn{6}{|c|}{ Response Results } \\
\hline & Statement & 1 & 2 & 3 & 4 & 5 \\
\hline 1 & $\begin{array}{l}\text { The media used } \\
\text { are easily } \\
\text { accessed }\end{array}$ & & & $15 \%$ & $85 \%$ & \\
\hline 2 & $\begin{array}{l}\text { I feel I can learn } \\
\text { more by using the } \\
\text { media provided }\end{array}$ & & & $10 \%$ & $80 \%$ & $10 \%$ \\
\hline 3 & $\begin{array}{l}\text { I found learning } \\
\text { media that made } \\
\text { me understand the } \\
\text { material more } \\
\text { deeply }\end{array}$ & & & $10 \%$ & $80 \%$ & $10 \%$ \\
\hline 4 & $\begin{array}{l}\text { I feel that the } \\
\text { videos and } \\
\text { modules } \\
\text { make learning } \\
\text { more fun }\end{array}$ & & & $15 \%$ & $85 \%$ & \\
\hline 5 & $\begin{array}{l}\text { I feel the choice of } \\
\text { language used is } \\
\text { easy to understand }\end{array}$ & & & $20 \%$ & $80 \%$ & \\
\hline 6 & $\begin{array}{l}\text { I find it easier to } \\
\text { understand the } \\
\text { material after } \\
\text { studying with the } \\
\text { module and video } \\
\text { media }\end{array}$ & & & $25 \%$ & $75 \%$ & \\
\hline 7 & $\begin{array}{l}\text { I feel that the } \\
\text { video and module } \\
\text { have the right and } \\
\text { comfortable } \\
\text { combination of } \\
\text { colors } \\
\text { graphics }\end{array}$ & & & $30 \%$ & $70 \%$ & \\
\hline 8 & $\begin{array}{l}\text { I feel the contents } \\
\text { in the module and } \\
\text { video are } \\
\text { consistent }\end{array}$ & & & $23 \%$ & $77 \%$ & \\
\hline
\end{tabular}

From the results of the discussion questionnaire responses, it shows that more answers lead to answers agree to strongly agree then it can be concluded that most students respond positively to learning media.

In addition to the questionnaire about which material is a favorite of students in learning during the pandemic is the effective technical material selling online, where students consider that the material on the topic is very relevant to the current situation.

\section{CONCLUSION}

From the discussion above the conclusions that can be drawn are as follows: The results showed that the learning tools in the form of modules and video salesmanship received very high responses, and were effective in fostering student interest in learning. The data analysis result from response's students showed that with the modules and video salesmanship makes learning easier and fun. 
On the topic of effective techniques selling online during the pandemic, it is very relevant to current needs. In which the material also gets a good response and becomes students' favorite material who take the Salesmanship class. Online implementation during the pandemic is indeed new but the lecturers are still consistently obey the procedure as face-to-face in which the lecturers are still adjusting the material to the RPS, guiding when participants carry out online activities, providing introductory material and also creating the suitability of final exam and mid-semester exam.

Suggestions for further research are to add some learning methods, it can also add several other variables that are more measurable. Perhaps it is also possible to add data that can be processed into quantitative data so that it can better present of the results.

\section{REFERENCES}

[1] Sugandi, Achmad, et al. Learning Theory. Semarang: UPT MKK UNNES

[2] Kemp, JE and Dayton, DK 1985. Planning and Producing Instructional Media. Cambridge: Harper \& Row Publishers, nnnnnnnnnew York.

[3] Holmberg, B.. The evolution, principles and practices of distance education. Bibliotheks und informations system der Univ. 2005

[4] Fee, KH. Delivering E-Learning: A Complete Strategy for Application Design and Assessment, London and Philadelphia: Kogan Page. 2005

[5] Cheng, K. A Research Study on Students' Level of Acceptance in Applying E-Learning for Business Courses - A Case Study on a Technical College in Taiwan. Journal of the American Academy of Business. Volume 8. Number 2. pp: 265-270. 2006

[6] Rusman, et al. Information and Communication Technology Based Learning. Jakarta: Raja Grafindo Persada. 2011

[7] Munir. Distance Learning Based on Information and Communication Technology. Bandung: Alfabeta. 2009

[8] Jaggars, SS. Choosing between online and face-to-face courses: Community college student voices. American Journal of Distance Education, 28 (1), 27-38. 2014
[9] Tunceren, L. L. ESL Students in an Online Community College Course: A Multiple Case Study. 2015

[10] Huang, XS, \& Hsiao, EL. Synchronous and asynchronous communication in an online environment: Faculty experiences and perceptions. Quarterly Review of Distance Education, 13 (1), 15-30. 2012. Retrieved from https: // w ww. learntechlib.org/p/131977/.

[11] Cornelius, S.. Facilitating in a demanding environment: Experiences of teaching in virtual classrooms using web conferencing. British Journal of Educational Technology, 45 (2), 260-271. 2014

[12] Akarasriworn, C., \& Ku, H. Y. Graduate students' knowledge construction and attitudes toward online synchronous videoconferencing collaborative learning environments. Quarterly Review of Distance Education, 2013, 14 (1), $35-48$.

[13] Lavolette, E., Venable, MA, Gose, E., \& Huang, E. . Comparing synchronous virtual classrooms: Student, instructor and course designer perspectives. TechTrends, 54 (5), 54 61.2010

[14] Reese, SA . Online learning environments in higher education: Connectivism vs. dissociation. Education and Information Technologies, 20 (3), 579-588. 2014

[15] Damayati and Mudjiono. Learning and learning. Jakarta: PT. Rineka Cipta. 2006.

[16] Hamalik, Oemar. 2003. Teaching Planning Based on a Systems Approach. Jakarta: PT. Earth Literacy.

[17] Morissan. Metode Penelitian Survey. Jakarta: Kencana Prenada Media Group. 2012.

[18] Guetterman, Tim, "Descriptions of Sampling Practices Within Five Approaches to Qualitative Research in Education and the Health Sciences" (2015). Educational Psychology Papers and Publications. 263.https://digitalcommons.unl.edu/edpsychpa pers $/ 263$

[19] Creswell, J. W. Educational research: Planning, conducting, and evaluating. W. Ross MacDonald School Resource Services Library. 2013

[20] Putri. R. S. et al.. Impact of the COVID-19 Pandemic on Online Home Learning: An Explorative Study of Primary Schools in Indonesia. International Journal of Advanced 
Science and Technology Vol. 29, No. 5, (2020), pp. 4809-4818

[21] Chakraborty, M. and Muyia Nafukho, F. "Strengthening student engagement: what do students want in online courses?", European Journal of Training and Development, Vol. 38 No. 9, pp. 782-802. 2014. 